\title{
Ketersediaan Ruang Terbuka Hijau (RTH) Taman dan Hutan Kota di Kota Jambi
}

\author{
Marhadi ${ }^{*}$ dan Hadrah ${ }^{2}$ \\ ${ }^{1,2}$ Progam Studi Teknik Lingkungan, Fakultas Teknik, Universitas Batanghari \\ Jl. Slamet Riyadi, Broni, Jambi \\ *Correspondence email: marhadi54@yahoo.co.id
}

\begin{abstract}
Green open space functions as a supporter and enhancer of the value of quality in the environment and culture of the city so that it can be allocated and shaped in its use in accordance with its needs and interests, Jambi City Regional Regulation No. 9 of 2013 concerning the Spatial Planning for the Jambi City Region in 2013-2033. Jambi City with an area of 205.38 $\mathrm{km}^{2}$ requires minimum public green open space of 4,107.60 ha and private green open space of at least 2.05.38 ha. Based on DLH data from Jambi City. In 2017, the City of Jambi still lacked 2,220.13 ha of public green space and 774.36 ha of private green space, the research objective identifying the extent and availability of urban parks and forests based on population and water demand approach. The research method uses data analysis criteria identifying the needs of parks and urban forests, population and water consumption. Identify the number and extent of urban parks and urban forests as many as 45 city parks and 2 urban forests in Jambi City and the largest urban parks are in the youth arena park located in Kota Baru District with an area of 2,008 ha, public open space city parks and urban forests jambi has a total area of 72,922 ha. The required green space in Jambi City is 4,107.6 ha, it is obtained that the area of public green space identified is only about $1.77 \%$ of the total area of the city. The needs of urban forest area based on the water approach that requires land until 2028 covering an area of 5,614.47 ha are less fulfilled, because the total available land is 58 ha with potential land of 79.85 ha, only 94.32 ha has been developed, but it can only meet the needs of the area of urban forests based on the water approach only in 2018 of $2,495.32 \mathrm{ha}$
\end{abstract}

Keywords : Alphabetically sorted; Capitalized first word; From a to z; Maximum 5 keywords; Separate by semicolon (;) between keyword

\section{Pendahuluan}

Ruang Terbuka Hijau (RTH) terdiri dari kawasan hijau hutan kota, kawasan hijau taman kota, kawasan hijau rekreasi kota, kawasan hijau kegiatan olahraga, dan kawasan hijau perkarangan. Dalam pemanfaatannya selain menambah nilai estetika dan keasrian kota, Menurut (Rahmania 2011) secara ekologis ruang terbuka hijau berfungsi sebagai perlindungan plasma nutfah dan keanekaragaman hayati. Sedangkan secara arsitektural, sosial dan ekonomi, ruang terbuka hijau berfungsi sebagai pendukung dan penambah nilai kualitas dalam lingkungan maupun kebudayaan kota sehingga dapat beralokasi dan berbentuk dalam pemanfaatan yang sesuai dengan kebutuhan dan kepentingannya. Kota Jambi dengan luas mencapai $205.38 \mathrm{~km}^{2}$ membutuhkan ruang terbuka hijau publik minimal 4.107,60 hektar dan ruang terbuka hijau privat minimal 2.05,38 hektar. Berdasarkan data DLH Kota Jambi. Tahun 2017, Kota Jambi masih kekurangan RTH publik 2.220,13 hektar dan RTH privat sebayak 774,36 hektar. Hal ini membuktikan, Kota Jambi masih belum memenuhi $30 \%$ ruang terbuka hijau sebagaimana yang tercantum dalam UU RI No 26 Tahun 2007.

Adapun tujuan penelitian ini Menganalisis kebutuhan dan mengidentifikasi luasan taman kota serta hutan kota ruang terbuka hijau di Kota Jambi berdasarkan UU RI. No. 26 Tahun 2007. Menganalisis ketersediaan ruang terbuka hijau hutan kota berdasarkan pendekatan pemenuhan kebutuhan air di Kota Jambi.

Ruang terbuka adalah salah satu bagian dari ruangruang yang terdapat di suatu kota yang biasanya merupakan wadah bagi kehidupan manusia dan mahkluk lainnya untuk dapat hidup dan berkembang secara berkelanjutan (Ebenezer Howard, 1961), sedangkan Ruang Terbuka Hijau menurut UU RI Nomor 26 Tahun 2007 tentang Penataan Ruang adalah area memanjang atau jalur dan atau mengelompok, yang penggunaannya lebih bersifat terbuka sebagai tempat tumbuh tanaman, baik yang tumbuh secara alamiah ataupun ditanam.

Sedangkan (Rustam Hakim, 1991) membagi ruang terbuka menjadi dua jenis yaitu:

Ruang terbuka aktif, yaitu ruang terbuka yang mengandung unsur-unsur kegiatan di dalamnya, seperti bermain, olah raga, dan upacara. Ruang terbuka ini dapat berbentuk plaza, lapangan olah raga, tempat bermain, penghijauan di tepi sungai, tempat rekreasi dan lain-lain.

Ruang terbuka pasif, yaitu ruang terbuka yang didalamnya tidak mengandung kegiatan manusia, seperti penghijauan sebagai jarak terhadap rel kereta api dan lain-lain.

\subsection{Ruang Terbuka Hijau Publik}

Berdasarkan Permen PU No. 05/PRT/M/2008 dinyatakan bahwa, taman kota adalah lahan terbuka yang berfungsi sosial dan estetik sebagai sarana kegiatan rekreasi, edukasi, atau kegiatan lain pada tingkat kota. Taman Kota sebagai ruang terbuka hijau (RTH) kota adalah bagian dari ruang terbuka (open spaces) suatu wilayah perkotaan yang diisi oleh tumbuhan, tanaman, dan vegetasi (endemik, introduksi)

Pengertian ruang publik secara singkat merupakan suatu ruang yang berfungsi untuk kegiatan-kegiatan masyarakat yang berkaitan dengan sosial, ekonomi, dan budaya.

Ruang publik adalah suatu tempat yang dapat menunjukkan perletakan sebuah obyek. Tempat ini dapat diakses secara fisik maupun visual oleh masyarakat umum. Dengan demikian ruang publik dapat berupa jalan, trotoar, taman kota, lapangan dan lain-lainnya.

Ruang umum terbuka adalah bentuk dasar dari ruang terbuka di luar bangunan dan dapat digunakan oleh publik (setiap orang) dan memberi kesempatan untuk bermacam- 
macam kegiatannya. Contoh: jalan, pedestrian, taman, plaza, makam, lapangan terbang, lapangan olah raga dan lainnya.

Taman kota sebagai ruang publik adalah memaksimalkan fungsi sosial dan estetika dari lahan terbuka hijau di antara bangunan yang berisi tumbuhan, tanaman, dan vegetasi sebagai sarana kegiatan rekreasi, edukasi, atau kegiatan lain pada tingkat kota.yang diperuntukan untuk umum untuk kegiatan sosial, ekonomi, dan budaya, serta bisa diakses secara fisik dan visual oleh masyarakat umum.

\subsection{Jenis-jenis RTH Publik Kawasan Perkotaan}

Menurut Peraturan Menteri No.1 Tahun 2007 tentang Penataan Ruang Terbuka Hijau Kawasan Perkotaan, jenis RTHKP meliputi:

\section{a. Taman Kota}

Taman Kota merupakan ruang didalam kota yang ditata untuk menciptakan keindahan, kenyamanan, keamanan, dan kesehatan bagi penggunanya. Taman kota dilengkapi dengan beberapa fasilitas untuk kebutuhan masyarakat kota sebagai tempat rekreasi. Selain itu, taman kota difungsikan sebagai paru-paru kota, pengendali iklim mikro, konservasi tanah dan air, dan habitat berbagai flora dan fauna.

\section{b. Taman Hutan Raya}

Taman Hutan Raya adalah kawasan pelestarian alam untuk tujuan koleksi tumbuhan dan atau satwa yang alami atau bukan alami, jenis asli dan atau bukan asli, yang dimanfaatkan bagi kepentingan penelitian, ilmu pengetahuan, pendidikan, menunjang budidaya, budaya, pariwisata dan rekreasi (Ditjenphka, 2010).

\section{c. Hutan kota}

Hutan kota adalah komunitas vegetasi berupa pohon dan asosiasinya yang tumbuh di lahan kota atau sekitarnya, berbentuk jalur, menyebar, membentuk habitat yang memungkinkan kehidupan bagi satwa liar dan menimbulkan lingkungan sehat, suasana nyaman, sejuk, dan estetis. Berdasarkan PP No. 63 Tahun 2002, hutan kota didefinisikan sebagai suatu hamparan lahan yang bertumbuhan pohon-pohon yang kompak dan rapat di dalam wilayah perkotaan baik pada tanah negara maupun tanah hak, yang ditetapkan sebagai hutan kota oleh pejabat yang berwenang.

\section{Metode Penelitian}

Penelitian ini dilaksanakan di Kota Jambi, Provinsi Jambi. Wilayah administratif Kota Jambi terdiri dari 11 kecamatan dan 90 kelurahan. Secara geografis Kota Jambi berada pada posisi $1^{\circ} 35^{\prime} 21^{\prime \prime} \mathrm{LU} 103^{\circ} 36^{\prime} 36^{\prime \prime} \mathrm{BT} / 1,58917^{\circ} \mathrm{LS}$ $103,61^{\circ} \mathrm{BT}$ dengan luas wilayah $\pm 205,38 \mathrm{~km}^{2}$

Objek dalam penelitian ini adalah kawasan ruang terbuka hijau publik diantaranya taman kota dan hutan kota yang ada di Kota Jambi. Unit pemetaan dan unit analisa yang digunakan dalam penelitian ini adalah unit lahan ruang terbuka hijau publik dan berdasarkan pemenuhan kebutuhan air masyarakat Kota Jambi

\subsection{Analisis Data}

Hasil analisis tersebut akan menjadi dasar kajian dalam menentukan luas area yang dibutuhkan untuk penyediaan ruang terbuka hijau pada lokasi penelitian dengan membandingkan pada luas RTH yang telah tersedia.
Analisis yang digunakan dalam penelitian ini adalah adalah analisis observasi data lapangan untuk mengetahui mengidentifikasi taman kota dan hutan kota ruang terbuka hijau yang telah ada dan menghitungan kebutuhan taman kota ruang terbuka hijau ini mengacu UU. No. 26 Tahun 2007.

Perhitungan kebutuhan hutan kota Ruang Terbuka Hijau Kota Jambi dihitung berdasarkan pendekatan pemenuhan kebutuhan air maka luas ruang terbuka hijau minimal 30\% dari luas Wilayah Kawasan Perkotaan.

\section{Hasil dan Pembahasan}

\subsection{Identifikasi Penyediaan Taman Kota dan Hutan Kota Ruang Terbuka Hijau Kota Jambi}

Identifikasi penyediaan ruang terbuka hijau ini berisikan bebeapa taman kota dan hutan kota ruang terbuka hijau dan luasannya yang ada terdapat dari 11 kecamatan dalam Kota Jambi (eksisting).

Tabel 1. Luasan RTH Publik di Kecamatan Telanaipura

\begin{tabular}{clcc}
\hline No & \multicolumn{1}{c}{ Nama dan Jenis RTH } & $\mathbf{M}^{\mathbf{2}}$ & $\mathbf{H a}$ \\
\hline 1 & Hutan Kota & 0 & 0 \\
2 & Taman PKK Murni / Tugu Pers & 354.57 & 0,0354 \\
3 & Taman Simpang Pulai & 466.47 & 0,0466 \\
4 & Taman Jaksa & 728.00 & 0,0728 \\
5 & Taman PPT/Tugu Broni & 240.00 & 0,024 \\
6 & Taman Perkebunan/ Kambang & 155.06 & 0,0155 \\
7 & Taman Ade Irma Suryani & 120.00 & 0,012 \\
8 & Taman Simpang Tanjung Lumut & 8.00 & 0,0008 \\
9 & Taman Simpang Rumah Sakit Umum & 25.00 & 0,0025 \\
10 & Taman Singkawang & 300.01 & 0,03 \\
11 & Taman Buluran Kenali & 363.30 & 0,0363 \\
12 & Taman Honda / Simpang 3 Sipin & 470.00 & 0,470 \\
& Total & $\mathbf{3 2 3 0 . 4 1}$ & $\mathbf{0 , 3 2 3 0}$ \\
\hline
\end{tabular}

Sumber : RTH di Kota Jambi, 2018

Kecamatan Telanaipura memiliki luasan wilayah 22,51 Ha. Dilihat dari tabel 4.1 diatas RTH di Kecamatan Telanaipura yang memiliki luasan total ruang terbuka hijau seluas 0,3230 ha, pada taman kota terluas yaitu pada Taman Jaksa seluas 0,0727 Ha, sedangkan luas RTH terendah luasannya yaitu taman Simpang Tanjung Lumut dengan luas 0,0008 Ha.

Tabel 2. Luasan RTH Publik Kota Jambi di Kecamatan Kota Baru

\begin{tabular}{clcc}
\hline No & \multicolumn{1}{c}{ Nama dan Jenis RTH } & $\mathbf{M}^{\mathbf{2}}$ & Ha \\
\hline 1 & Hutan Kota & 0 & 0 \\
2 & Taman Kirab Remaja & 47.00 & 0,0047 \\
3 & Taman Tugu Keris Siginjay & 1627.43 & 0,162 \\
4 & Taman Arena Remaja & 20086.00 & 2,08 \\
5 & Taman Tugu Juang 1 & 10671.16 & 1,067 \\
6 & Taman Tugu Juang 2 & 50.42 & 0,0050 \\
7 & Taman Tugu Juang 3 & 49.98 & 0,0049 \\
8 & Taman Tugu Juang 4 & 53.02 & 0,0053 \\
9 & Taman Tugu Juang 5 / Air Mancur & 332.99 & 0,0332 \\
10 & Taman Jalak Perumnas Kota Baru & 225.00 & 0,0225 \\
11 & Taman Kepondang Perumnas Kota Baru 3 & 290.00 & 0,0290 \\
12 & Taman Kepondang Perumnas Kota Baru 2 & 768.84 & 0,0768 \\
13 & Taman Kepondang Perumnas Kota Baru 1 & 445.90 & 0,0445 \\
14 & Taman Kong Kow & 11274.52 & 1,1274 \\
\multicolumn{2}{c}{ Total } & $\mathbf{4 . 6 6 2 3 , 6 7}$ & $\mathbf{4 , 6 6 2 3}$ \\
\hline
\end{tabular}

Sumber : RTH di Kota Jambi, 2018

Kecamatan Kota Baru memiliki luasan wilayah 36,11 Ha. Dilihat dari tabel 4.2 diatas RTH di Kecamatan Kota Baru 
yang memiliki luasan total taman kota ruang terbuka hijau seluas 4,6623 Ha. pada taman kota terluas yaitu pada Arena Remaja 2,08 Ha, sedangkan terendah luasannya yaitu taman Kirab Remaja dengan luas 0,0047 Ha.

Tabel 3. Luasan RTH Publik Kota Jambi di Kecamatan Danau

\begin{tabular}{|c|c|c|c|}
\hline \multicolumn{4}{|c|}{ Sipin } \\
\hline No & Nama dan Jenis RTH & $\mathbf{M}^{2}$ & Ha \\
\hline$\overline{1}$ & Hutan Kota & 0 & 0 \\
\hline 2 & Taman Kota & 0 & 0 \\
\hline \multicolumn{2}{|c|}{ Total } & 0 & 0 \\
\hline
\end{tabular}

Sumber : RTH di Kota Jambi, 2018

Kecamatan Danau Sipin dengan luasan wilayah 7,88 Ha. Dilihat dari tabel 4.3 diatas RTH di Kecamatan Danau Sipin tidak memiliki luasan total taman kota dan Hutan Kota.

Tabel 4. Luasan RTH Publik Kota Jambi di Kecamatan Alam Barajo

\begin{tabular}{cccc}
\hline No & Nama dan Jenis RTH & $\mathbf{M}^{\mathbf{2}}$ & Ha \\
\hline 1 & Hutan Kota M. Sabki & 110.000 & 11,00 \\
2 & Hutan Bagan Peta & 470.000 & 47,00 \\
3 & Taman Kota & 0 & 0 \\
& & $\mathbf{5 8 0 . 0 0 0}$ & $\mathbf{5 8 , 0 0}$ \\
\hline
\end{tabular}

Sumber : RTH di Kota Jambi, 2018

Kecamatan Alam Barajo dengan luasan wilayah 41,67 Ha. Dilihat dari tabel 4.4 diatas RTH di Kecamatan Alam Barajo memiliki taman kota luasan total $58 \mathrm{Ha}$, pada Hutan kota terluas yaitu pada Hutan Bagan Pete dengan luas $47 \mathrm{Ha}$, sedangkan terendah luasannya yaitu Hutan Kota M. Sabki dengan luas $11 \mathrm{Ha}$, sedangkan untuk taman kota di Kecamatan Alam Barajo belum ada.

Tabel 5. Luasan RTH Publik Kota Jambi di Kecamatan Jambi Selatan

\begin{tabular}{|c|c|c|c|}
\hline No & Nama dan Jenis RTH & $\overline{\mathbf{M}^{2}}$ & $\mathrm{Ha}$ \\
\hline 1 & Taman Adipura & 1298.10 & 1,29 \\
\hline 2 & Taman Sekapur Sirih & 221.95 & 0,0221 \\
\hline 3 & Taman PKK The Hook & 1210.15 & 1,210 \\
\hline 4 & Taman Anjungan Kota & 4000 & 4,00 \\
\hline 5 & Taman Simpang Beringin & 12.00 & 0,0012 \\
\hline 6 & Taman Belakang Persijam & 221.55 & 0,0221 \\
\hline 7 & Taman Ujung Bandara Baru & 5.00 & 0,0005 \\
\hline 8 & Taman Bundaran Bandara Baru & 2.00 & 0,0002 \\
\hline 9 & Taman Tugu Selamat Datang & 68.00 & 0,0068 \\
\hline & Total & 6733.25 & 6,733 \\
\hline
\end{tabular}

Sumber : RTH di Kota Jambi, 2018

Kecamatan Jambi Selatan dengan luasan wilayah 11,41 Ha.Dilihat dari tabel 4.5 diatas RTH di Kecamatan Jambi Selatan taman kota memiliki luasan total 6,733 Ha. pada taman Anjungan Kota terluas yaitu 4,00 $\mathrm{Ha}$, sedangkan terendah luasannya yaitu taman Bundaran Bandara Baru dengan luas 0,0002 Ha.

Tabel 6. Luasan RTH Publik Kota Jambi di Kecamatan Jambi Timur

\begin{tabular}{|c|c|c|c|}
\hline No & Nama dan Jenis RTH & $\mathbf{M}^{2}$ & Ha \\
\hline 1 & Hutan Kota & 0 & 0 \\
\hline 2 & Taman Tepian Tembuku & 916.79 & 0,916 \\
\hline & Total & 916.79 & 0,916 \\
\hline
\end{tabular}

Sumber : RTH di Kota Jambi, 2018
Kecamatan Jambi Timur dengan luasan wilayah 15,94 Ha. Dilihat dari tabel 4.6 diatas RTH di Kecamatan Jambi Timur taman kota memiliki luasan total taman kota pada taman Tepian Tembuku seluas 0,916 Ha dan tidak memiliki Hutan Kota.

Tabel 7. Luasan RTH Publik Kota Jambi di Kecamatan Pasar Jambi

\begin{tabular}{clcc}
\hline No & \multicolumn{1}{c}{ Nama dan Jenis RTH } & $\mathbf{M}^{\mathbf{2}}$ & Ha \\
\hline 1 & Hutan Kota & 0 & 0 \\
2 & Taman Tanggo Rajo & 248.47 & 0,0248 \\
3 & Taman Simpang Jelutung & 66.00 & 0,0066 \\
4 & Taman TP. Sriwijaya 1 & 487.13 & 0,0487 \\
5 & Taman Makalam & $1,017.25$ & 1,017 \\
6 & Taman Jembatan Makalam & 10.00 & 0,0010 \\
& Total & $\mathbf{1 0 9 8 . 1}$ & $\mathbf{1 , 0 9 8 1}$ \\
\hline
\end{tabular}

Sumber : RTH di Kota Jambi, 2018

Kecamatan Pasar Jambi dengan luasan wilayah 4,02 Ha.Dilihat dari tabel 4.7 diatas RTH di Kecamatan Pasar Jambi taman kota memiliki luasan total 1,098 Ha. pada taman Makalam terluas yaitu 1,017 $\mathrm{Ha}$, sedangkan terendah luasannya yaitu taman Jembatan Makalam dengan luas 0,0010 Ha.

Tabel 8. Luasan RTH Publik Kota Jambi di Kecamatan Paal Merah

\begin{tabular}{cccc}
\hline No & Nama dan Jenis RTH & $\mathbf{M}^{\mathbf{2}}$ & Ha \\
\hline 1 & Hutan Kota & 0 & 0 \\
2 & Taman Kota & 0 & 0 \\
& Total & $\mathbf{0}$ & $\mathbf{0}$ \\
\hline
\end{tabular}

Sumber : RTH di Kota Jambi, 2018

Kecamatan Paal Merah dengan luasan wilayah 27,13 Ha. Dilihat dari tabel 4.8 diatas RTH di Kecamatan Paal Merah tidak memiliki luasan total taman kota dan Hutan Kota.

Tabel 9. Luasan RTH Publik Kota Jambi di Kecamatan Jelutung

\begin{tabular}{cccc}
\hline No & Nama dan Jenis RTH & $\mathbf{M}^{\mathbf{2}}$ & Ha \\
\hline 1 & Hutan Kota & 0 & 0 \\
2 & Taman Kota & 0 & 0 \\
& Total & $\mathbf{0}$ & $\mathbf{0}$ \\
\hline
\end{tabular}

Sumber : RTH di Kota Jambi, 2018

Kecamatan Jelutung dengan luasan wilayah 7,92 Ha Dilihat dari tabel 4.8 diatas RTH di Kecamatan Jelutung tidak memiliki luasan total taman kota dan Hutan Kota.

Tabel 10. Luasan RTH Publik Kota Jambi di Kecamatan Pelayangan

\begin{tabular}{clcc}
\hline No & \multicolumn{1}{c}{ Nama dan Jenis RTH } & $\mathbf{M}^{2}$ & Ha \\
\hline 1 & Hutan Kota & 0 & 0 \\
2 & Taman Sanggar Batik & 1147.13 & 1,114 \\
& $\quad$ Total & 1147.13 & 1,114 \\
\hline
\end{tabular}

Sumber : RTH di Kota Jambi, 2018

Kecamatan Pelayangan dengan luasan wilayah 15,29 Ha. Dilihat dari tabel 4.10 diatas RTH di Kecamatan Pelayangan memiliki luasan total taman kota pada taman Sanggar Batik seluas 1,114 Ha dan tidak memiliki Hutan Kota. 
Tabel 11. Luasan RTH Publik Kota Jambi di Kecamatan Danau Teluk

\begin{tabular}{clcc}
\hline No & \multicolumn{1}{c}{ Nama dan Jenis RTH } & $\mathbf{M}^{\mathbf{2}}$ & Ha \\
\hline 1 & Hutan Kota & 0 & 0 \\
2 & Taman Aur Duri & 140.87 & 0,0140 \\
3 & Taman Simpang Danau Teluk & 7.50 & 0,0075 \\
& Taman Simpang Polsek Danau & 276.91 & 0,0276 \\
4 & Teluk & 275.87 & 0,0275 \\
5 & Taman Pasir Panjang & 766.65 & 0,0766 \\
\hline
\end{tabular}

Sumber : RTH di Kota Jambi, 2018

Kecamatan Danau Teluk dengan luasan wilayah 16,7 Ha. Dilihat dari tabel 4.11 diatas RTH di Kecamatan Danau Teluk taman kota memiliki luasan total 0,0766 Ha. pada taman Simpang Polsek Danau Teluk terluas yaitu 0,0276 Ha, sedangkan terendah luasannya yaitu taman Simpang Danau Teluk dengan luas 0,0075 Ha.

Tabel 12. Total Luas RTH Publik Taman Kota dan Hutan Kota Jambi

\begin{tabular}{ccccc}
\hline No & Kecamatan & $\begin{array}{c}\text { Luas } \\
\text { Eksisting } \\
\text { (Ha) }\end{array}$ & $\begin{array}{c}\text { Luas RTH } \\
\text { sekarang } \\
\text { (Ha) }\end{array}$ & $\begin{array}{c}\text { \% Dari } \\
\text { Luas } \\
\text { Kecamatan }\end{array}$ \\
\hline 1 & Telanaipura & 22,51 & 0,3230 & 1.43 \\
2 & Kota Baru & 36,11 & 4,6623 & 0.077 \\
3 & Danau Sipin & 7,88 & 0 & 0 \\
4 & Alam Barajo & 41,67 & 58 & 71.844 \\
5 & Jambi Selatan & 11,41 & 6,733 & 169.46 \\
6 & Jambi Timur & 15,94 & 0,916 & $1.740,17$ \\
7 & Pasar Jambi & 4,02 & 1,098 & 36,61 \\
8 & Paal Merah & 27,13 & 0 & 0 \\
9 & Jelutung & 7,92 & 0 & 0 \\
10 & Pelayangan & 15,29 & 1,1140 & $1.372,53$ \\
11 & Danau Teluk & 15,7 & 0,0766 & $20.496,08$ \\
& Total & $\mathbf{2 0 5 . 3 8}$ & $\mathbf{7 2 , 9 2 2}$ & \\
\hline
\end{tabular}

Sumber : RTH di Kota Jambi, 2018

Berdasarkan Tabel 4.12 RTH di Kota Jambi yang memiliki luasan tertinggi adalah RTH pada Kecamatan Alam Barajo memiliki Hutan Kota untuk ruang terbuka hijau seluas $58 \mathrm{Ha}$ atau dan taman kota total luas RTH taman dan hutan kota di Kota Jambi adalah 14,922 Ha.

\subsection{Analisis Potensi Penyediaan RTH untuk Taman Kota dan Hutan Kota}

Persebaran lahan potensial untuk taman kota pada setiap kecamatan-kecamatan di Kota Jambi yang dapat di kembangkan menjadi RTH Publik dapat dilihat pada lahan kosong dan pertanian. Total luas lahan potensial yaitu 40,869 Ha. Untuk lebih jelasnya dapat dilihat pada Tabel 16.

Tabel 16. Luas Lahan Non Terbangun untuk Taman Kota

\begin{tabular}{ccc}
\hline No & Kecamatan & Luas (Ha) \\
\hline 1 & Telanaipura & 6,43 \\
2 & Kota Baru & 6,170 \\
3 & Danau Sipin & 2,364 \\
4 & Jambi Selatan & 3,31 \\
5 & Jambi Timur & 3,866 \\
6 & Pasar Jambi & 0,108 \\
7 & Paal Merah & 8,139 \\
8 & Jelutung & 2,376 \\
9 & Pelayangan & 3,473 \\
10 & Danau Teluk & 4,6334 \\
& Total & 40,869 \\
\hline
\end{tabular}

Sumber : Hasil Analisis, 2018
Berdasarkan tabel 16 di atas bahwa lahan non terbangun yang ada di Kota Jambi terdiri dari lahan pertanian dan lahan kosong dengan kecamatan yang memiliki luas lahan non terbangun terluas di Kota Jambi terdapat pada Kecamatan Paal Merah yaitu seluas 8,139 Ha, sedangkan luas lahan non terbangun yang paling kecil terdapat pada Kecamatan Pasar Jambi yaitu dengan luas $0,108 \mathrm{Ha}$.

Hasil overlay lahan non terbangun dengan rencana pola ruang di Kota Jambi tahun 2018 hanya memiliki luas lahan potensial yang dapat di kembangkan menjadi untuk taman kota yaitu 40,689 $\mathrm{Ha}$, dengan jenis lahan non terbangun yaitu pertanian yang berada di sebagian kecil untuk lebih jelasnya dapat dilihat pada Gambar 1.

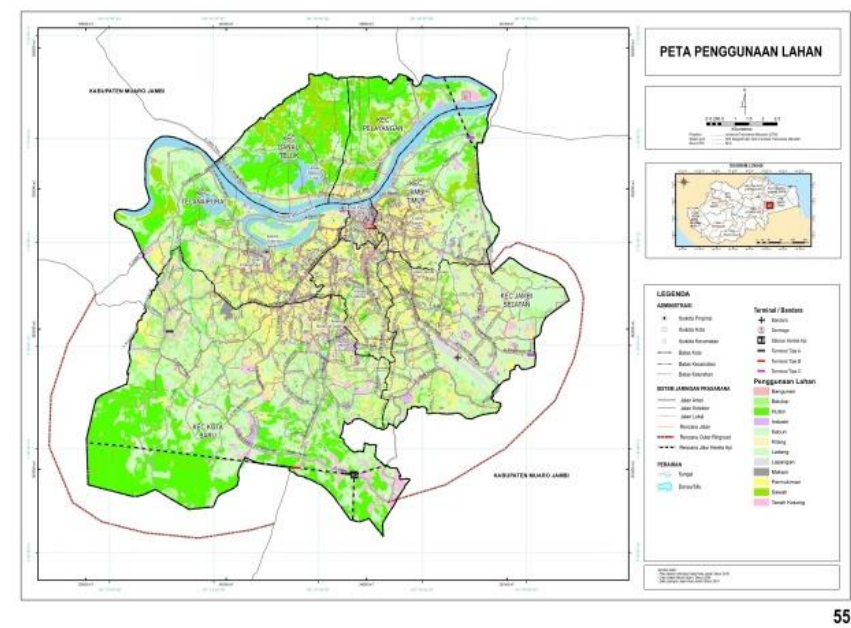

Gambar 1. Peta Penggunaan Lahan

Berdasarkan data tersebut jika di bandingkan dengan kebutuhan luas RTH taman publik maka lahan yang tersedia belum memenuhi total luas yang dibutuhkan oleh karena itu perlu analisis lebuh lanjut untuk perencanaan RTH yang tidak menggunakan lahan kosong seperti taman vertical atau jenis lain yang memungkinkan bagi daerah padat penduduk, Dapat di lihat pada gambar 2 .

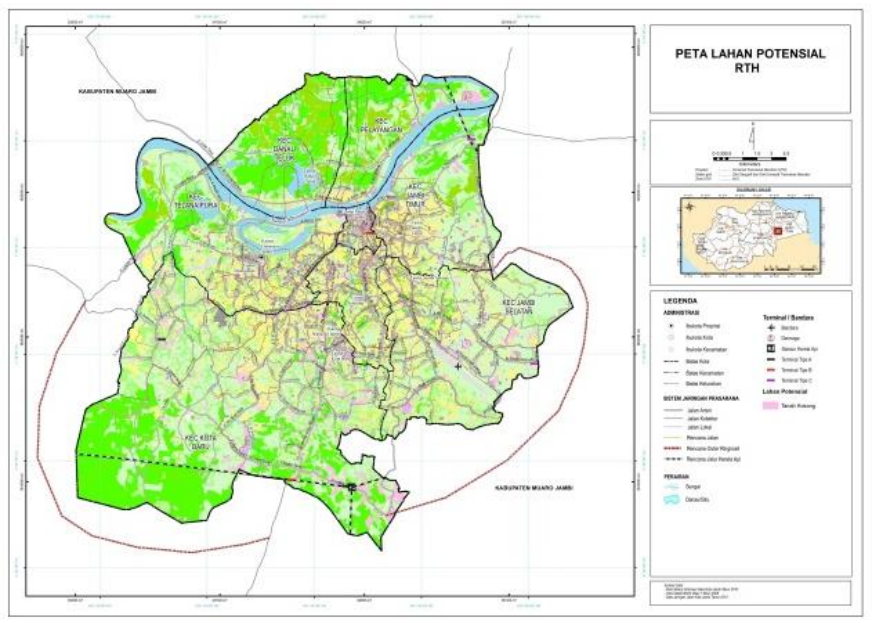

Gambar 2. Peta Lahan Potensial

\subsection{Pemetaan Rencana Pengembangan Taman Kota dan Hutan Kota}

Total RTH keseluruhan dari penyediaan eksisting dengan yang perlu adanya penambahan untuk dikembangkan hanya dapat dipenuhi $14,66 \%$ dari wilayah kota maka perlu adanya pengembangan RTH untuk memenuhi kesesuaian 
menurut UU No. 26 Tahun 2007 yaitu $30 \%$ RTH Publik taman kota dan hutan kota seluas 5,34 \% dari wilayah kota. Untuk lebih jelasnya dapat dilihat pada Tabel 17.

Tabel 17. Peta Rencana Pengembangan RTH di Kota Jambi

\begin{tabular}{ccccc}
\hline No & Jenis RTH & $\begin{array}{c}\text { Luas } \\
\text { Penyediaan } \\
\text { Eksisting (Ha) }\end{array}$ & $\begin{array}{c}\text { Penambahan } \\
\text { RTH } \\
\text { (Ha) }\end{array}$ & $\begin{array}{c}\text { Total tiap } \\
\text { jenis RTH }\end{array}$ \\
\hline 1 & Hutan Kota & 58 & 559.4 & 617.4 \\
2 & Taman Kota & 14,922 & 40,869 & 55,791 \\
& Total & 72,922 & 599.869 & 6196.4 \\
\hline
\end{tabular}

Sumber : Hasil Analisis, 2018

Pada Tabel 17 bahwa kebutuhan luas Hutan Kota berdasarkan pendekatan air yang membutuhkan lahan hingga tahun 2028 seluas 5,614.47 Ha kurang terpenuhi, karena total lahan penyediaan eksisting $58 \mathrm{Ha}$ dengan lahan potensial 79,85 Ha, maka yang dikembangkan hanya 94,32 Ha, melainkan hanya dapat memenuhi kebutuhan luas Hutan Kota berdasarkan pendekatan air hanya pada tahun 2018 sebesar 2,495.32 Ha, dengan demikian masih kurangnya lahan yang diperuntukan untuk memenuhi penambahan Hutan Kota yaitu 559.4 Ha. Untuk Taman Kota yang membutuhkan penambahan RTH seluas 40,869 Ha. Untuk RTH Luas lahan potensial yang diperuntukan untuk pengembangan RTH Taman Kota dan Hutan Kota hanya seluas 599.4 Ha dengan total keseluruhan seluas $6196.4 \mathrm{Ha}$.

\section{Kesimpulan}

Berdasarkan kajian yang dilakukan dapat diketahui bahwa luas total ruang terbuka hijau (RTH) di kota Jambi adalah sebesar 14,922 Ha. Perlu adanya penambahan RTH dari penyediaan eksisting untuk dikembangkan dan hanya dapat dipenuhi 14,66 \% dari wilayah kota berdasarkan ketersediaan lahan di Kota Jambi, maka perlu adanya pengembangan RTH untuk memenuhi kesesuaian menurut UU No. 26 Tahun 2007 yaitu 30 \% RTH Publik taman kota dan hutan kota seluas 5,34\% dari wilayah kota

\section{Daftar Pustaka}

Fandeli, C. 2004. AMDAL dalam Pembangunan. Liberty. Yogyakarta

Grey GW, Deneke FJ. 1986. Urban Forestry (Second Edition). New York: J. Wiley

Gold, Seymour M (1980). Recreation Planning and Design. United States of America. McGraw-Hill,Inc

Hakim, Rustam. 1991. Unsur Perancangan dalam Arsitektur Lanskap. Bumi Aksara. Jakarta.

Hakim, Rustam dan H. Utomo. 2003. Komponen Perancangan Arsitektur Lanskap PrinsipUnsur dan Aplikasi Desain. Bumi Aksara. Jakarta.

Howard, Ebenezer, Garden City Of To-Morow, Faber and Ltd, London, 1961.

http://urbanplanning.library.cornell.edu/DOCS/howard.htm

Instruksi Mendagri Nomor 14 Tahun 1988 . tentang Perbandingan Prosentase mengenai Wilayah Ruang Terbuka Hijau dan ruang terbangun dalam wilayah suatu perkotaan.

Peraturan Pemerintah No. 34 Tahun 2006 Tentang Jalan.

Permen PU No. 05/PRT/M/2008 Tentang Pedoman Penyediaan Dan Pemanfaatan Ruang Terbuka Hijau di Kawasan Perkotaan.
Peraturan Menteri Dalam Negeri No. 4 Tahun 1980 tentang Pedoman Rencana Kota

Peraturan Menteri Dalam Negeri No.1 Tahun 2007 tentang Penataan Ruang Terbuka Hijau Kawasan Perkotaan

Rapuano, Michael, P.P. Pirone, and Brooks E. Wigginton, 1964 Open Space In Urban Design, The Cleveland Development Foundation, Cleveland, Ohio. Tersedia : Hilman Firmanyah Tugas Akhir, Tahun 2008. "Kajian Kebutuhan Ruang Terbuka Hijau Guna Menanggulangi Pencemaran Udara Di Pusat Kota Cianjur". Jurusan Teknik Planologi, Universitas Pasundan,

Simonds, John Ormbee, Landscape Architecture, McGrawHill Book Company, USA, 1983

Simond, J.O., Landscape Architecture, Mc Grow-Hill Book Co. New York, 1984. 2. Tersedia : Iman Harwafi, Tugas Akhir 2013. "Kajian Konsep Pengembangan "Green Corridor" dalam rangka menanggulangi pencemaran udara akibat kendaraan bermotor pada koridor jalan buah batu Kota Bandung”. Jurusan Teknik Planologi, Universitas Pasundan

Shirvani, Hamid. 1985. The Urban Design Process. Van Nostrand Reinhold: New York.

Undang-Undang Republik Indonesia Nomor 26 Tahun 2007 tentang Penataan Ruang 